\title{
MINAT BACA MELALUI MAJALAH DIGITAL STUDI KASUS : MAHASISWA PENDIDIKAN INFORMATIKA UNIVERSITAS TRUNOJOYO MADURA
}

\author{
Medika Risnasari \\ Universitas Trunojoyo Madura \\ Bangkalan, Indonesia \\ medika.risna@trunojoyo.ac.id
}

\begin{abstract}
Abstrak
Kebiasaan membaca dan menulis masih belum berkembang dengan sepenuhnya pada anggota-anggota masyarakat, khususnya bagi kalangan pelajar dan mahasiswa. Minat dan kebiasaan membaca yang baik, merupakan faktor penting dari kebiasaan yang tak mungkin dimiliki dalam waktu singkat.

Majalah digital dapat menjadi media pembelajaran dalam bentuk majalah yang merupakan sebuah produk teknologi yang mampu menampilkan tampilan bacaan baru dalam format digital. Adanya majalah digital akan berpengaruh terhadap minat membaca mahasiswa Pendidikan Informatika. Sehinggga dalam penelitian ini, dibuat majalah digital yang berisi materi mata kuliah Basis Data. Kvisoft Flipbook Maker merupakan salah satu software untuk membuat majalah digital.

Hasil yang didapat penelitian ini adalah banyaknya mahasiswa Pendidikan Informatika yang mempunyai minat baca terhadap majalah digital dan hasil pembuatan majalah digital mampu menjadi media pembelajaran dalam menyajikan materi kuliah dengan nilai validitas 3,016.
\end{abstract}

Kata kunci: minat baca, majalah digital, Kvisoft Flipbook Maker

\begin{abstract}
Generally, many people have not the habit of reading, especially for the students. Interest and good reading habits, is an important factor of habit that can not be held in a short time.

Digital magazine is one of a media of learning in the form of a magazine which is a product have a new display of reading in a digital format. The existence of the digital magazine will affect the students read models especially for informatic technology students.. So in this research, we make a Database digital magazine which is a one of course in information technology depatement. Kvisoft Flipbook Maker is a software to create digital magazines.

The results of this researce is the number of informatics technology read to the digital magazine and the results of making database digital magazines as a media of learning has validity value 3.016.
\end{abstract}

Keywords: reading, digital magazines, Kvisoft Flipbook Maker 


\section{PENDAHULUAN}

Minat dan kebiasaan membaca yang baik, merupakan faktor penting dari budaya tulisan yang tidak mungkin dimiliki dalam waktu singkat. Untuk mencapai pengembangannya membutuhkan waktu yang ralatif lama dan harus sejalan dengan perkembangan pendidikan. Penggunaan media pembelajaran yang sesuai adalah salah satu usaha yang dilakukan oleh pengajar dalam mengembangkan potensi mahasiswa. Menurut Azhar Arsyad (2003), fungsi beberapa majalah konvensional mencoba untuk memanfaatkan laju teknologi tersebut dengan melakukan proses digitalisasi ke dalam bentuk elektronik dengan harapan dapat tetap hidup dan mempertahankan pangsa pasar yang sudah ada.

Majalah digital termasuk salah satu pembelajaran berbasis komputer atau Computer Based Instruction (CBI) yang membuat peserta didik belajar individual dan madiri. CBI pun dapat sebagai tutor yang menggantikan pendidik di dalam kelas. Majalah digital adalah satu produk kemajuan teknologi dalam bidang komunikasi dan informasi

Secara keseluruhan mahasiswa menggunakan media elektronik termasuk majalah digital sebagai sumber untuk mencari suatu informasi dibandingkan dengan mencari di media cetak. Selain cepat mencarinya media elektronik juga sangat menarik karena dilengkapi dengan gambar-gambar yang menarik.

Di sisi lain, mahasiswa juga mengetahui akan dampak dari kemajuan media elektronik terhadap minat baca mereka. Selain banyaknya mahasiswa yang menggunakan media elektronik sebagai utama media pendidikan adalah sebagai alat bantu mengajar yang turut mempengaruhi iklim, kondisi, dan lingkungan belajar yang ditata dan diciptakan oleh guru.

Majalah merupakan salah satu media baca yang digunakan manusia untuk memenuhi kebutuhan akan informasi. Seiring dengan berkembangnya teknologi yaitu dengan kemunculan internet, majalah konvensional menjadi kurang diminati oleh masyarakat. Hal tersebut membuat

sumber untuk mencari suatu informasi tetapi ada sebagian mahasiswa yang menggunakan media cetak untuk mencari suatu informasi.

Berbagai cara dilakukan oleh mahasiswa untuk mempunyai minat baca yang pada umumnya diawali dengan membaca buku cerita, novel, komik, karon dan lainnya. Seiring dengan perkembangan teknologi informasi dan peralatan yang memadai, maka banyak mahasiswa lebih sering melakukan koneksi internet/online sebagai media menarik minat baca.

Dengan berbagai perilaku kebiasaan mahasiswa terhadap minat baca terutama pada mahasiswa pendidikan informatika melalui majalah digital, maka peneliti dalam penelitian "Minat Baca Melalui Majalah Digital Studi Kasus: Mahasiswa Pendidikan Informatika Universitas Trunojoyo Madura" akan menarik minat baca mahasiswa terhadap mata kuliah yang diajarkan dalam perkuliahan. Keinginan untuk mendesain tampilan majalah digital yang menarik minat baca maka diawali dengan layout, pewarnaan yang menarik kemudian memberi konten yang mudah untuk dibaca. Selain itu konten yang actual akan 
memberikan daya tarik minat baca karena rasa ingin mengetahui perkembangan berita.

\section{METODE PENELITIAN}

Penelitian ini merupakan penelitian yang menggambarkan kemampuan majalah digital untuk meningkatkan minat baca oleh mahasiswa dan pemngembangan media pembelajaran dalam bentuk majalah digital.Subjek penelitian adalah sasaran pengguna produk yaitu mahasiswa pendidikan informatika angkatan 2014 sebanyak 128 mahasiswa dan diambil sampel sebanyak 40 mahasiswa di lingkungan kampus Universitas Trunojoyo Madura.

Pada penelitian ini, langkahlangkah yang dilakukan adalah

1. Studi literature, untuk menentukan media pembelajaran interaktif yang sesuai untuk mahasiswa pendidikan informatika

2. Pengumpulan data untuk mengetahui tingkat minat baca mahasiswa dengan cara menyebarkan angket yang kemudian dilakukan evaluasi angket. Selain itu pada pengumpulan data dilakukan penyusunan materi mata kuliah basis data.

3. Pembuatan majalah digital, dalam penelitian menggunakan software Kvisoft Flipbook Maker

4. Pengujian keseluruhan yaitu melakukan validitas majalh digital yang telah dibuat kepada responden

5. Deskrip hasil yaitu melakukan evaluasi dari pengujian majalah digital.

\section{HASIL DAN PEMBAHASAN}

Hasil dari penyebaran angket ke mahasisiwa pendidikan informatika angkatan 2014 sebanyak 40 mahasiswa mengenai tingkat minat baca adalah sebagai berikut:

Tabel 1. Data Minat Majalah

Digital atau Cetak

\begin{tabular}{lc}
\hline Jenis Majalah & Jumlah \\
\hline Majalah Digital & 35 \\
Majalah Cetak & 5 \\
\hline
\end{tabular}

Dari data di atas, dapat dilihat bahwa mahasiswa Program Studi Pendidikan Informatika mayoritas menyukai membaca majalah digital. Sedangkan jenis majalah yang disukai oleh mahasiswa sangat beragam sesuai dengan kecenderung kesukaan mereka.

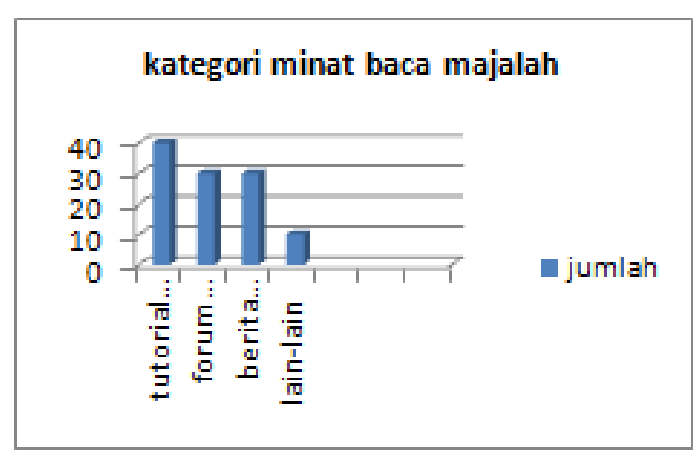

Gambar 1. Kategori Minat baca majalah

Data tabel di atas menunukkan bahwa minat baca mahasiswa bergantung kepada kesukaan masing-masing. Tabel di atas, semua mahasiswa menyukai majalah teknologi informasi. Keadaan seperti wajar, karena dasar pendidikan jenjang S1 mereka memilih pendidikan informatika, sehingga basic informatika sudah mereka. Pilihan mahasiswa terbanyak kedua yaitu wisata, dan majalah olah raga berada pada 
peringkat kedua dan di susul oleh desain interior serta otomotif dan resep makanan dan terakhir lain-lain yang hanya dipilih oleh 5\% mahasiswa.

Dari berbagai macam keunggulan majalah digital di atas, peneliti mencoba mengajukan beberapa pilihan pernyataankepada responden untuk mengetahui pilihan alasan mereka senang membaca majalah digital. Hasil penelitian terhadap para responden dapat dirangkum dalam tabel penelitian di bawah ini.

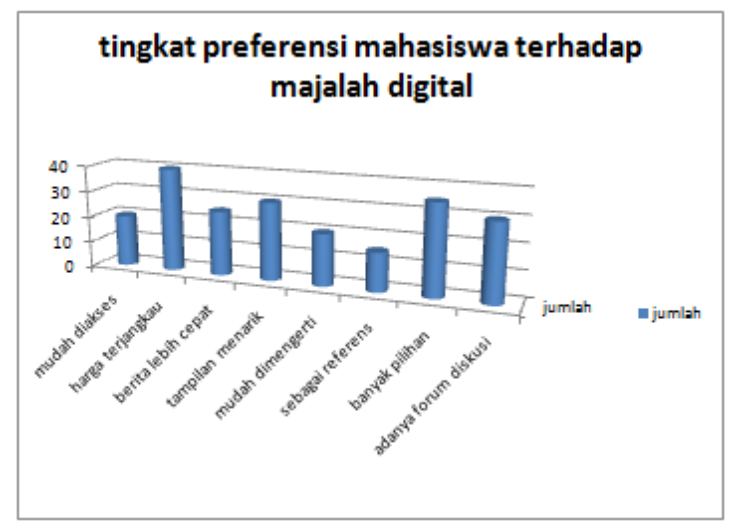

Gambar 2. Tingkat preferensi mahasiswa terhadap majalah digital

Gambaran data di atas menunjukkan bahwa harga terjagkau menjadi alasan utama mahasiswa memilih majalah digital sebagai bahan bacaan. Apalagi dengan semakin canggihya teknologi informasi membantu mempermudah dalam mengakses majalah digital. Tekhnologi telepon membantu mempermudah sekaligus mempermurah akses majalah digital, sebab dengan telepon yang berbasis android sudah berfungsi sebagai server internet, sehingga biaya yang dibutuhkan mengakses majalah digital menjadi murah dan lebih mudah.
Keunggulan pada kemudahan dan murah dipilih oleh hampir semua reponden yaitu berjumlah 40 orang mahasiswa.

Selanjutnya, peneliti mangajukan tawaran kepada para responden tentang relevansi kontens majalah digital dengan materi kuliah di PIF supaya minat baca yang tingi dapat mendukung terhadap prestasi akademik mahasiswa. Gambaran tanggapan responden terhadap tawaran tersebut dapat dilihat dari diagram di bawah ini.

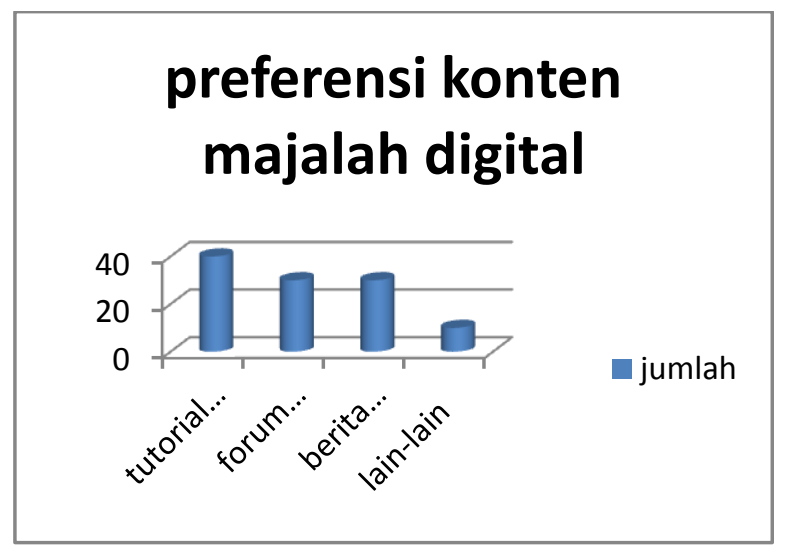

Gambar 3. Preferensi Konten Majalah Digital

Dari data di atas, dapat dipahami bahwa pilihan tertinggi mahasiswa terhadap konten majalah digital terletak padatutorial matakuliah sehingga lebih mempermudah mahasiswa mengakses matakuliah yang tertentu dengan nyaman dan menarik.

Setelat peneliti melakukan evaluasi terhadap minat baca maka selanjutkan dilakukan pembuatan majalh digital. Berikut hasil dari majalah digital untuk mata kuliah basis data yang merupakan mata kuliah pada semester gasal 2015/2016: 


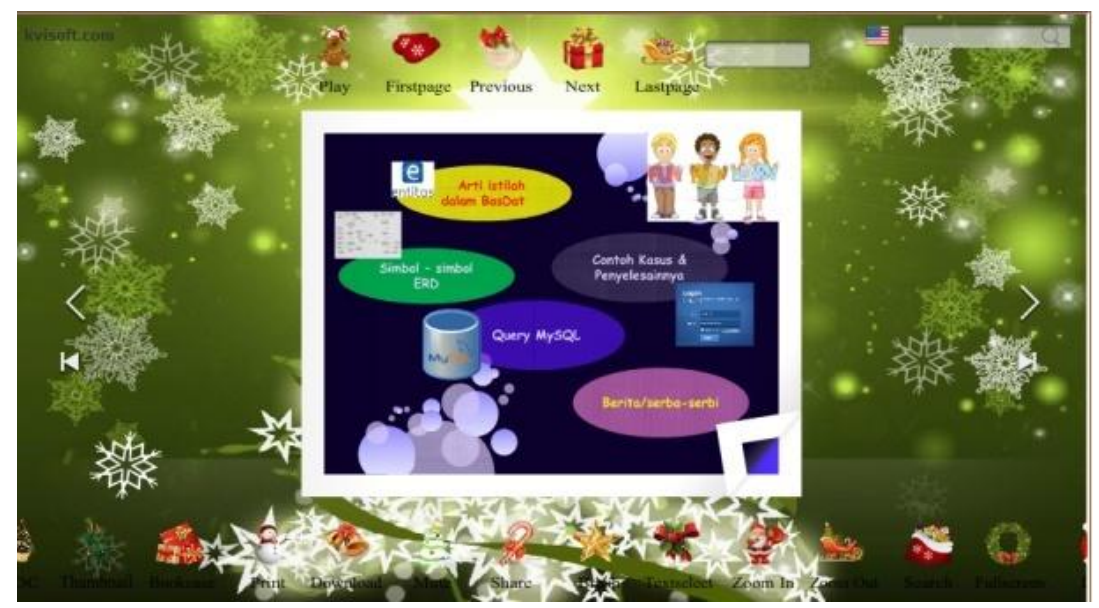

Gambar 4 . Halaman awal Majalah Digital

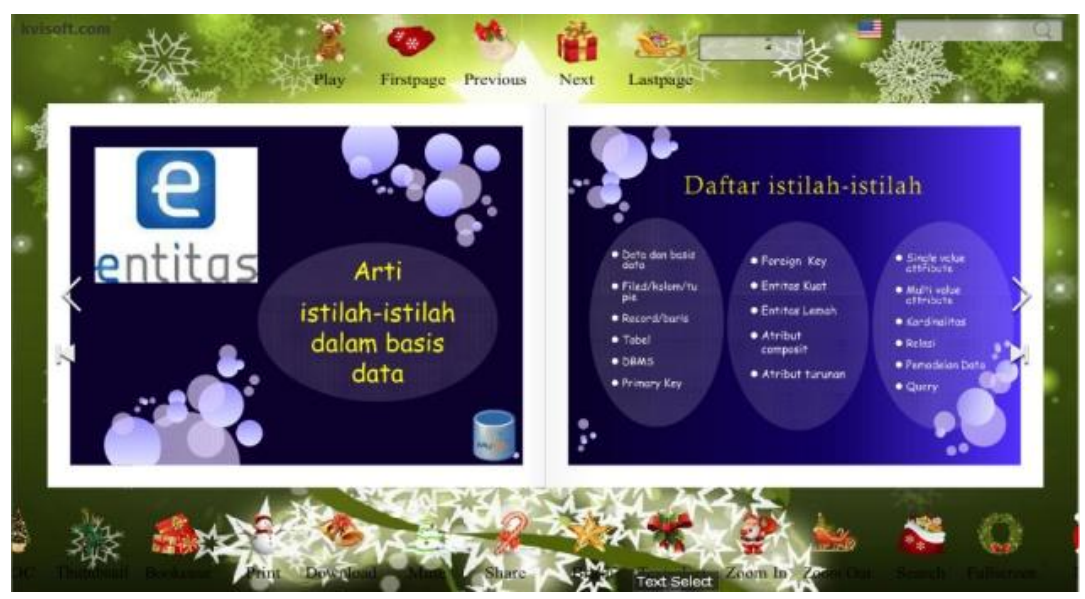

Gambar 5 . Tampilan majalah digital

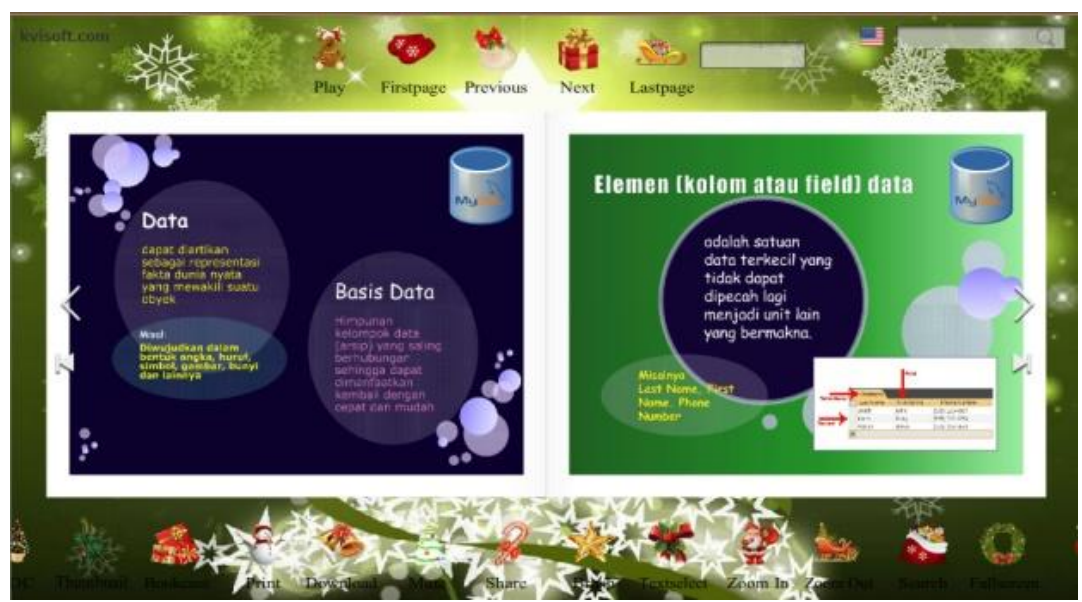

Gambar 6 . Tampilan majalah digital

Dari gambar 4,5 dan 6 didapat sebuah majalah digital yang menyajikan materi mata kuliah basis data seperti istilah-istilah yang banyak digunakan oleh mahasiswa dalam memahami mata kuliah basis data. Sebuah majalah digital dengan konten mata kuliah basis data dikemas dengan memberikan isi materi yang sangat 
perlu dipahami oleh mahasiswa. Untuk mengurangi kejenuhan dan tampilan yang menoton, maka penulisan dalam majalah digital haruslah singkat, jelas dan tuntas. Sehingga dalam majalah digital perlu pengelolaan materi yang disajikan dengan tepat. Selain dari cara penulisan, dalam majalah digital juga diperlukan penyisipan gambar-gambar yang mudah untuk dipahami sebagai representasi.

Dari hasil penyebaran angket kebeberapa mahasiswa Pendidikan informatika terhadap majalah digital pada tabel 2 .

Tabel 2. Hasil Skor validasi majalah digital

\begin{tabular}{|c|l|c|c|c|c|c|c|l|}
\hline \multirow{2}{*}{ No } & Pernyataan & \multicolumn{4}{|c|}{ Responden/skor } & \multirow{2}{*}{$\begin{array}{l}\text { Skor } \\
\text { total }\end{array}$} & \multirow{2}{*}{ Rata-rata } & Kriteria \\
\cline { 3 - 6 } & & 1 & 2 & 3 & 4 & & \\
\hline 1 & Desain & 2 & 28 & 5 & 5 & 84 & 2.9 & Cukup Baik \\
\hline 2 & Tampilan warna & 0 & 0 & 10 & 30 & 150 & 3.75 & Sangat baik \\
\hline 3 & Tampilan navigasi & 0 & 5 & 25 & 10 & 125 & 3,125 & Baik \\
\hline 4 & Tampilan materi & 0 & 0 & 10 & 30 & 150 & 3.75 & Sangat Baik \\
\hline 5 & Kemudahan akses & 1 & 30 & 8 & 1 & 89 & 2,23 & Cukup Baik \\
\hline 6 & Interaktif & 0 & 30 & 8 & 2 & 92 & 2.3 & Cukup Baik \\
\hline
\end{tabular}

Berdasarkan tabel 3 , maka didapatkan skor total sebesar 690 yang digunakan untuk mengetahui validditas majalah digital dengan menggunakan 40 orang sebagai responden sehingga diperoleh skor rata-rata sebesar 3,01 sehingga dapat disimpulkan desain ,ajalah digital dikatakan valid, artinya majalah digital masik layak untuk digunakan oleh mahasiswa Pendidikan Informatika.

Kriteria untuk penskoran adalah sebagai berikut :

Rata-rata 0,00 - 1,99= Kurang baik

Rata-rata 2,00 - 2,99 = Cukup valid

Rata-rata 3,00 - 3,49= Baik

Rata-rata 3,50 - 4,00 = Sangat Baik

Secara keseluruhan hasil validasi majalah digital dengan menggunakan menggunakan teknik analisis nilai ratarata, diadaptasi dari pendapat Arikunto. Arikunto (2006:242) menyatakan bahwa untuk mengetahui peringkat terakhir untuk butir yang bersangkutan, jumlah nilai tersebut harus dibagi dengan banyaknya responden yang menjawab angket tersebut.

Kriteria untuk penskoran adalah sebagai berikut :

Rata-rata $0,00-1,99=$ Tidak valid

Rata-rata 2,00 - 2,99 = Kurang valid

Rata-rata 3,00 - 3,49= valid

Rata-rata 3,50 - 4,00 = Sangat valid

\section{KESIMPULAN DAN SARAN}

Berdasarkan tujuan penelitian dan hasil beserta pembahasan diperoleh beberapa kesimpulan sebagai berikut:

Dari hasil penelitian ini didapat beberapa kesimpulan, antara lain:

1. Sebanyak 35 mahasiswa dari 40 mahasiswa Pendidikan Informatika angkatan 2014 mempunyai minat baca terhadap majalah digital dan 5 mahasiswa lebih menyukai majalah cetak 
2. Mahasiswa Pendidikan Informatika angkatan 2014 lebih banyak membaca majalah digital dengan topik teknologi informasi sebgai upaya mereka dalam memperdalam ilmu seiring dengan program studi yang diikuti di kampus Univeristas Trunojoyo madura

3. Majalah digital menggunakan Kvisoft Flipbook Maker dapat dijadikan sebagai media pembelajaran dalam menyajikan materi kuliah

4. Majalah digital yang diujicobakan pada mata kuliah Basis Data mempunyai validasi 3.016 sebagai parameter layak untuk digunakan oleh mahasiswa

\section{SARAN}

Penelitian "Minat Baca Melalui Majalah Digital Studi Kasus: Pendidikan Informatika niversitas Trunojoyo Madura" masih banyak memerlukan perbaikan, yaitu:

1. Penyajian tampilan yang lebih interaktif

2. Dapat digunakan diberbagai platform seperti smartphone, tablet PC dan lainnya

\section{DAFTAR PUSTAKA}

Arikunto, suharsimi. 2002. Prosedur Penelitian Suatu Pendekatan Praktek. Jakarta: PT Rineka Cipta Arsyad, Azhar. 2011. Media Pembelajaran. Jakarta: RajaGrafindo Persada Benge, Ronald C.1986. Libraries and Cultural Change. London:Clive Bingley
Ghulam Nurul Huda, "Dampak Kemajuan Media Elektronik Terhadap Minat Baca Para Pelajar Indonesia"

Aditya dwi nugroho dan javislam pradipta putra, 2013, "Pembuatan Dan Publikasi Majalah Digital "Destiny God” Dengan Menggunakan Adobe Flash Cs, Amikom Yogyakarta

Muller, Derek Alexander. 2008. Designing Effective Multimedia for Physics Education. Thesis. Sydney : School of Physics University of Sydney.

www.wikipedia.co.id

http://www.kaduthokcay77.com/2014/11/d ownload-kvisoft-flipbook-makerpro-4220-full-version.html 
